\title{
Prevalence of hepatitis B and C viral infections in Pakistan: findings of a national survey appealing for effective prevention and control measures
}

\author{
H. Qureshi, ${ }^{1}$ K.M. Bile, ${ }^{2}$ R. Jooma, ${ }^{3}$ S.E. Alam ${ }^{4}$ and H.U.R. Afridi ${ }^{2}$
}

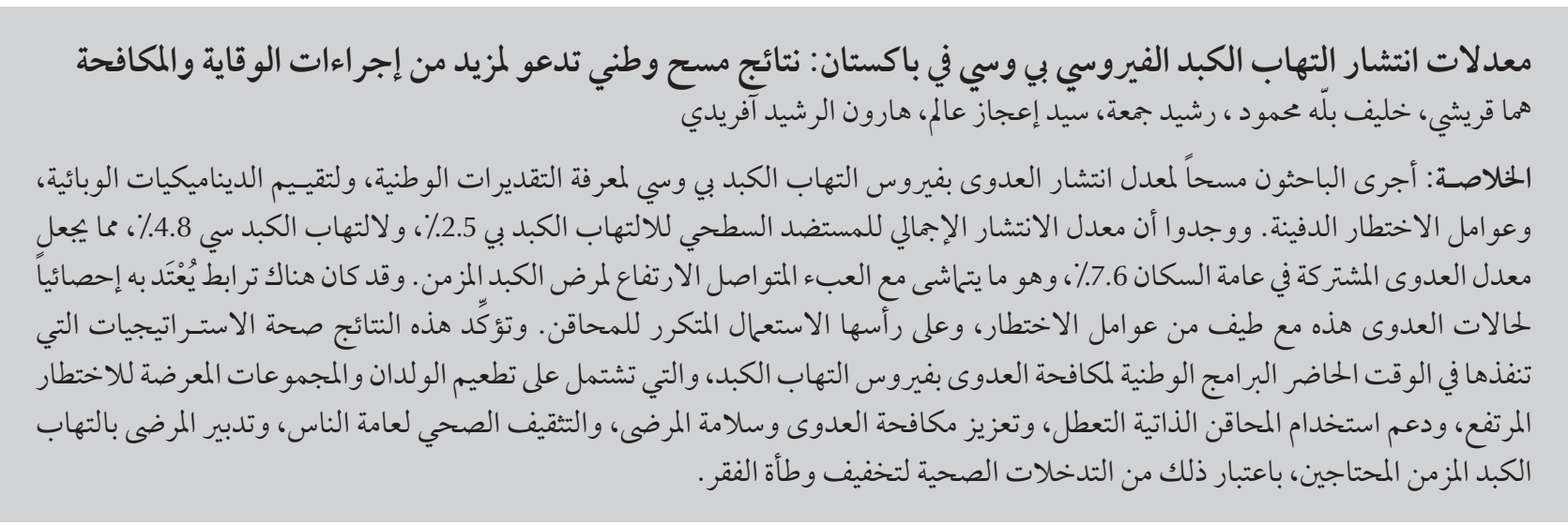

ABSTRACT A prevalence survey on hepatitis B and C infections was carried out to obtain national estimates and assess epidemiological dynamics and underlying risk factors. Overall prevalence of hepatitis B surface antigen ( $\mathrm{HBsAg})$ and anti-hepatitis $\mathrm{C}$ virus (HCV) of $2.5 \%$ and $4.8 \%$, respectively, reflected a combined infection rate of $7.6 \%$ in the general population, consistent with an ongoing high burden of chronic liver disease (CLD). There was significant association of these viral infections with a range of risk factors led by reuse of syringes. These findings validate currently implemented strategies by the national programme for the control of hepatitis viral infections, including universal vaccination of newborns and high-risk groups, support of auto-disable syringes, promotion of infection control and patient safety, public health education, and management of needy CLD patients as a poverty-reduction health intervention.

Prévalence des infections virales de l'hépatite B et de I'hépatite C au Pakistan : résultats d'une enquête nationale appelant à des mesures de lutte efficaces

RÉSUMÉ Une enquête de prévalence sur les infections par les virus de l'hépatite B et de l'hépatite C a été réalisée afin d'obtenir des estimations nationales et d'évaluer la dynamique épidémiologique et les facteurs de risque sous-jacents. La prévalence globale de l'antigène de surface du virus de l'hépatite B et celle des anticorps antivirus de l'hépatite C étaient de 2,5\% et 4,8\% respectivement, reflétant un taux global d'infection de $7,6 \%$ dans la population générale, ce qui est cohérent avec la charge actuelle élevée d'affections hépatiques chroniques. Une association importante de ces infections virales avec de nombreux facteurs de risque liés à la réutilisation des seringues a été observée. Ces résultats attestent du bien-fondé des stratégies du programme national de lutte contre les infections par le virus de l'hépatite, à savoir : vaccination universelle des nouveau-nés et des groupes à haut risque, soutien à l'utilisation de seringues autobloquantes, promotion de la lutte contre les infections et de la sécurité des patients, éducation à la santé publique et prise en charge des patients nécessiteux atteints d'affections hépatiques chroniques en tant qu'intervention sanitaire visant à réduire la pauvreté.

'Pakistan Medical Research Council, Islamabad, Pakistan.

${ }^{2}$ World Health Organization, Country Office, Islamabad, Pakistan (Correspondence to K.M. Bile: bilek@pak.emro.who.int).

${ }^{3}$ Ministry of Health, Islamabad, Pakistan.

${ }^{4}$ Jinnah Postgraduate Medical Centre, Karachi, Pakistan. 


\section{Introduction}

Hepatitis B virus (HBV) and hepatitis $\mathrm{C}$ virus (HCV) infections contribute to the global public health threats confronting most developing countries, where health care systems lack the safety measures necessary to avert the risks of infection and public awareness about the modes of transmission is insufficient [1-3]. A large number of HBV and HCV studies have been carried out in Pakistan over the past two decades, restricted to clinical and hospital-based settings, blood bank institutions and small communities that could not validly demonstrate the distribution of $\mathrm{HBV}$ and HCV in the general population, though corroborating the existence of a high burden of chronic liver disease (CLD) in the country [4-7].

Since 1994, the World Health Organization (WHO) has worked with the Federal Ministry of Health substantiating the urgency of adding hepatitis B vaccine to the roster of the national Expanded Programme on Immunization (EPI) and of its provision to all newborn children in order to build a nationwide lifelong immunity against HBV and eliminate the burden of HBV-related CLD, including primary hepatocellular carcinoma. This recommendation was outlined in 1992 by WHO, with the goal of integrating hepatitis $B$ vaccine into routine EPI by $1997[8,9]$.

This aspiration was realized in 2002, through the financial support of the Global Alliance for Vaccines and Immunization (GAVI Alliance) and with WHO technical support, leading to the procurement of $\mathrm{HBV}$ vaccines for over 4 million newborns annually. This arrangement was sustained until 2008, when the pentavalent diphtheria-tetanus-pertussis-hepatitis B-Haemophilus influenzae type b (DTP-HepB-Hib) vaccine cofinancing mechanism was introduced.

However, in a populous nation like Pakistan, the need for additional preventive interventions and the management of a large pool of vulnerable patients with HBV- and HCV-related CLD required a national hepatitis $\mathrm{B}$ and $\mathrm{C}$ control programme with a preventive and curative scope of implementation. The high prevalence of HCV detected by multiple cross-sectional studies added to the alarm, as it is known that over $80 \%$ of HCV-infected individuals progress into CLD $[1,10]$. In 2004, the Ministry of Health developed the first project document of a national hepatitis control programme with federal funding, technically supported by WHO. This landmark was substantiated in 2005 when the national exchequer earmarked a 5-year budgetary allocation of Rs 2.594 billion, then equivalent to US\$ 43 million. The launching of the programme was facilitated by the strong political support, the growing public concern and the call for action resonated by professional groups, civil society organizations and the media, to contain an impending public health disaster. The programme scope included: vaccination of highrisk groups; safety of blood and blood products; safe injections and invasive devices; hospital waste management; behavioural change communication and hospital-based surveillance.

To substantiate the high burden of HBV and HCV infections and influence the government planning and financing institutions to offer a tangible, long-term budgetary outlay, there was a need to undertake a nationwide HBV and HCV survey that would guide the planning and implementation of hepatitis prevention and control interventions. This paper reports the findings of this survey, which generated credible and representative national data about the high prevalence of $\mathrm{HBV}$ and $\mathrm{HCV}$ infections, and established the basis for future national control interventions and outcome evaluations.

\section{Methods}

The survey was conducted in urban and rural areas of all four provinces and territories of Pakistan, excluding the Federally Administered Tribal Areas and a few other security-compromised areas, cumulatively accounting for about $3 \%$ of the total population. The applied sampling frame was designed by the Federal Bureau of Statistics and classified cities and towns into well-defined enumeration blocks with 200-250 households each, based on the 1998 census population update carried out in 2004 for urban settings; for rural areas the 1998 census data were applied as no similar update was available.

These enumeration blocks and villages constituted the primary sampling units (PSUs), representing urban and rural areas, respectively. The PSUs were further specified for a group of 14 large mega-cities, each forming a separate structure that was further subdivided into low-, middle- and high-income groups, based on earlier data collected from these enumeration blocks. The remaining urban areas constituted one structure labelled "the other urban areas", while the rural area of each district of the four provinces was considered as a separate structure, except in the sparsely populated province of Balochistan, where the provincial administrative divisions each aggregating several districts were considered as the unit for the stratum.

Considering the characteristics of the variables to be estimated, the population distribution and available resources, 7000 sample households were considered necessary to attain reliable estimates of HBV and HCV prevalence for national and provincial levels and indicative data about districts. Sample households were drawn from 350 PSUs, 138 urban and 212 rural. Relatively more PSUs were drawn from urban areas to account for their socioeconomic diversity. In the sample selection, urban enumeration blocks and villages were selected as PSUs, based on the "probability proportional to size" sampling method. Subsequently, households within PSUs were selected with equal 
probability using a systematic sampling technique with random start. Thus 3500 households were selected from Punjab province; 1560 from Sindh; 1100 from Khyber Pakhtunkhwa, formerly the North Western Frontier Province; and 840 from Balochistan. An average family size was 6.5 persons. For sample testing for hepatitis B and hepatitis $C$, rapid tests were used which were enzyme-linked immunosorbent assay (ELISA) compared, before being procured [Abbott Determine ${ }^{\text {ww }}$ for hepatitis B surface antigen (HBsAg), Advanced Quality" One Step HCV Test (Bionike Inc.) for anti-HCV).

A consent form to be completed by each family head, a family form, an individual form and a report form for feedback of results were prepared. An information brochure was produced to brief families about the objectives of the study. A referral form was also prepared for those needing further medical investigations. All forms were translated into the national language Urdu for easy field application and were field tested prior to survey implementation for validation and fine tuning. All testing surveyors were laboratory technicians who were further trained on how to share the information brochure with the family head, explain the survey objectives and obtain consent for sampling family members, either by signing a consent form or through a thumb impression, in the presence of at least two family members. The laboratory technician surveyors were trained on how to run $\mathrm{HBV}$ and $\mathrm{HCV}$ rapid tests using whole blood, and on how to mark names on the devices and on storage gel tubes where the PSU code, house number and person's number and name were to be recorded. The tested blood kit devices, once checked, were pasted on the individual report forms to keep a record, while the reports were written on the back of individual forms to ensure that, if devices were lost, the written report remained. Blood was collected in gel tubes and serum was separated and stored for further testing.

Hepatitis B e antigen ( $\mathrm{HBeAg}$ ) was tested on all HBsAg-positive sera that were stored for future use using the chemiluminescence method, carbonylmetalloimmunoassay.

To access targeted PSUs and households to be tested, survey teams contacted local health authorities and Federal Bureau of Statistics staff, who provided names of the households, easing identification of the correct houses. At the household level, blood tests were run in a row on all individuals, rapid tests carried out and results provided before leaving the house within 15-20 minutes.

The house was marked after completing the survey. The teams were to visit all 20 houses of a PSU and seek the help of the local statistical office for replacement in the case of refusal or absence of family members. The Pakistan Medical Research Council closely monitored the work of the survey teams, assessing the accuracy of their access to the selected PSUs and contact with the identified households, and confirming that tests had been carried out. Any operational inconsistencies observed were then rectified to sustain the validity of the survey implementation.

The survey commenced in July 2007 and was completed in May 2008. The testing results were recorded using SPSS, version 13.0 and subsequently analysed. Statistical differences were estimated using the chi-square test, the odds ratio (OR) and 95\% confidence interval (CI) measures. The data were disaggregated by province and district, although the district data were not robust, thus allowing conservative inferences at that level.

\section{Results}

This nationwide community survey was concluded in 11 months and was successful in reaching out to $96 \%$ of families and individuals selected from the 350 PSUs outlined in the study sample size. The non-tested $4 \%$ were due to migration, non-availability of the household members at the time of the visit, or refusals.

Of the families in the sample, $87.6 \%$ owned their residential homes. Of the 7000 houses visited, $32.0 \%$ were made of mud, $45.4 \%$ were made of bricks and plastered walls, $19.3 \%$ were of semi-solid material, while $3.3 \%$ of the houses were well-furnished modern constructions, indicating the wide socioeconomic diversity of the tested population.

Piped drinking water was available in $52.7 \%$ of the houses; $21.8 \%$ of the families obtained water from nearby public taps; 9.7\% used well water; 5\% fetched water from a spring, pond or river; and $10.8 \%$ received water through tankers, or mule or donkey carts.

Sanitation conditions varied: $26.5 \%$ did not have any toilet facilities at home; $18.5 \%$ used pit latrines; and 55\% had flush toilets.

Excluding preschoolchildren, $44.4 \%$ of screened individuals were illiterate, while $17 \%$ had education below the primary level; of the remaining individuals who had completed primary education, $2 \%$ had completed 10 years of schooling and only $1 \%$ had graduate education.

Of the tested adult populations $41.4 \%$ were housewives or home-based self-employed, $25.5 \%$ were students, $15.5 \%$ were employed at private or public sector institutions, while the rest were unskilled workers.

A history of jaundice was recalled by $3 \%$ of screened individuals, while $3 \%$ reported having one family member who suffered from liver disease. The screened families also reported 496 family members who had died from liver disease. In the study population, the overall prevalence of HBsAg was $2.5 \%$, while anti-HCV prevalence was $4.8 \%$.

Table 1 illustrates HBsAg and anti-HCV prevalence in the study 


\begin{tabular}{|c|c|c|c|c|c|}
\hline \multicolumn{6}{|c|}{$\begin{array}{l}\text { Table } 1 \text { Prevalence of hepatitis B surfe } \\
\text { hepatitis C virus (anti-HCV) by sex }\end{array}$} \\
\hline \multirow[t]{2}{*}{ Sex } & \multirow[t]{2}{*}{ No. of subjects } & \multicolumn{2}{|c|}{ HBsAg positive } & \multicolumn{2}{|c|}{ Anti-HCV positive } \\
\hline & & No. (\%) & OR $(95 \% \mathrm{CI})$ & No. (\%) & OR $(95 \% \mathrm{Cl})$ \\
\hline Female & 22599 & $447(2.0)$ & 1 & $1090(4.8)$ & 1 \\
\hline Male & 24444 & 709 (2.9) & $1.48(1.31-1.67)$ & $1204(4.9)$ & $1.02(0.94-1.11)$ \\
\hline Total & 47043 & $1156(2.5)$ & & $2294(4.8)$ & \\
\hline
\end{tabular}

$C I=$ confidence interval; $O R=$ odds ratio

population, disaggregated by gender. Prevalence of anti-HCV did not show any gender difference, while HBsAg prevalence was significantly higher in males $(\mathrm{OR}=1.48$; $95 \% \mathrm{CI}: 1.31-1.67)$.
Table 2 shows HBsAg prevalence disaggregated by age, gender, marital status and history of injection use. The data illustrate age- and gender-related differences with a linear trend in the
20 years and above age and gender strata until the 40-49 years age group $(P<0.01)$. No difference in HBsAg was found between the two youngest age categories or between the 40-49 years age group and higher age categories. Currentlymarriedindividualshad significantly higher $\mathrm{HBsAg}$ positivity relative to those having no history of marriage (OR $=1.96$; 95\% CI: 1.57-2.45).

Males with a history of injection use had significantly higher HBsAg prevalence relative to those not reporting injection use; this was true for females only when comparing those with 5-10

\begin{tabular}{|c|c|c|c|c|c|c|}
\hline \multirow[t]{2}{*}{ Variable } & \multicolumn{2}{|c|}{ Males } & \multicolumn{2}{|c|}{ Females } & \multicolumn{2}{|c|}{ Total } \\
\hline & No. (\%) & OR $(95 \% \mathrm{Cl})$ & No. (\%) & OR $(95 \% \mathrm{Cl})$ & No.(\%) & OR $(95 \% \mathrm{CI})$ \\
\hline \multicolumn{7}{|l|}{ Age (years) } \\
\hline$<5$ & $33(1.6)$ & 1 & $20(1.0)$ & 1 & $53(1.3)$ & 1 \\
\hline $5-19$ & $198(2.1)$ & $1.33(0.90-1.96)$ & $131(1.5)$ & $1.56(0.95-2.57)$ & $329(1.8)$ & $1.42(1.05-1.92)$ \\
\hline $20-29$ & $104(2.4)$ & $1.55(1.03-2.35)$ & $88(2.1)$ & $2.17(1.30-3.64)$ & $192(2.2)$ & $1.79(1.30-2.46)$ \\
\hline $30-39$ & $106(3.7)$ & $2.45(1.63-3.72)$ & $81(2.8)$ & $2.91(1.74-4.91)$ & $187(3.2)$ & $2.61(1.90-3.60)$ \\
\hline $40-49$ & $104(4.5)$ & $2.97(1.97-4.50)$ & $63(3.0)$ & $3.11(1.83-5.34)$ & $167(3.8)$ & $3.04(2.20-4.20)$ \\
\hline $50-59$ & $82(5.5)$ & $3.70(2.41-5.68)$ & $34(2.6)$ & $2.72(1.51-4.92)$ & $116(4.1)$ & $3.37(2.40-4.75)$ \\
\hline$\geq 60$ & $82(5.0)$ & $3.32(2.16-5.10)$ & $30(2.7)$ & $2.79(1.53-5.13)$ & $112(4.0)$ & $3.28(2.33-4.62)$ \\
\hline Total & 709 (3.0) & & $447(2.0)$ & & $1156(2.5)$ & \\
\hline \multicolumn{7}{|l|}{$\begin{array}{l}\text { Marital status (20-49 } \\
\text { years) }\end{array}$} \\
\hline Never married & $67(1.9)$ & 1 & $36(1.7)$ & 1 & $103(1.8)$ & 1 \\
\hline Married & $245(4.2)$ & $2.32(1.75-3.09)$ & $193(2.8)$ & $1.70(1.70-2.47)$ & $438(3.4)$ & $1.96(1.57-2.45)$ \\
\hline $\begin{array}{l}\text { Divorced/separated/ } \\
\text { widowed }\end{array}$ & $2(2.7)$ & $1.49(0.0-6.3)$ & $3(1.5)$ & $0.88(0.27-2.84)$ & $5(1.8)$ & $1.01(0.36-2.59)$ \\
\hline Total & $314(3.3)$ & & $232(2.5)$ & & $546(2.9)$ & \\
\hline \multicolumn{7}{|l|}{$\begin{array}{l}\text { No. of intramuscular } \\
\text { injections }\end{array}$} \\
\hline None & $111(1.9)$ & 1 & $87(1.7)$ & 1 & $198(1.8)$ & 1 \\
\hline$<5$ & 359 (3.1) & $1.68(1.35-2.09)$ & $215(2.0)$ & $1.13(0.87-1.47)$ & $574(2.5)$ & $1.42(1.20-1.68)$ \\
\hline $5-10$ & $177(3.3)$ & $1.83(1.43-2.34)$ & $114(2.2)$ & $1.87(1.54-2.26)$ & $291(2.8)$ & $1.55(1.29-1.81)$ \\
\hline$>10$ & $62(4.4)$ & $2.43(1.75-3.37)$ & $31(2.0)$ & $1.17(0.76-1.80)$ & $93(3.2)$ & $1.78(1.38-2.30)$ \\
\hline Total & 709 (2.9) & & $447(2.0)$ & & $1156(2.5)$ & \\
\hline \multicolumn{7}{|l|}{ Types of syringes } \\
\hline None & $115(1.9)$ & 1 & $83(1.7)$ & 1 & $198(1.8)$ & 1 \\
\hline New disposable & $201(2.5)$ & $1.35(1.06-1.71)$ & $124(1.6)$ & $0.96(0.72-1.29)$ & $325(2.1)$ & $1.16(0.97-1.39)$ \\
\hline Re-used syringes & $332(3.7)$ & $1.99(1.60-2.49)$ & $206(2.4)$ & $1.40(1.08-1.83)$ & $538(3.0)$ & $1.71(1.44-2.02)$ \\
\hline Don't know & $65(4.6)$ & $2.48(1.80-3.42)$ & $30(2.2)$ & $1.30(0.83-2.02)$ & $95(3.4)$ & $1.92(1.48-2.47)$ \\
\hline Total & $706(2.9)$ & & $450(2.0)$ & & $1156(2.5)$ & \\
\hline
\end{tabular}

$C I=$ confidence interval; $O R=$ odds ratio. 
injections with non-users. Males using disposable syringes had significantly higher HBsAg prevalence relative to non-injection users, while this was not found among females. Likewise, no significant difference was found in HBsAg prevalence between females with lesser numbers of injections relative to those with higher numbers, while such a difference was significant for males with 10 or more injections relative to those with less than five. Table 3 illustrates prevalence of anti-HCV, disaggregated by age, gender, marital status and injection use. A significant increase in anti-HCV prevalence was observed distinctly in both genders of all age categories relative to the two youngest age groups. The most prominent increase in HCV infection rate was found among those aged between 20 and 49 years of age $(P<0.01)$. However, no antiHCV gender-based differences were found. Individuals with history of marriage had significantly higher anti-HCV prevalence compared with those with no history of marriage ( $\mathrm{OR}=2.01 ; 95 \%$ CI: 1.72-2.34).

With regard to injection use, antiHCV prevalence was significantly higher among users of any number of injections in both genders relative to non-users, while a similar difference was found in both genders between the different gradients of injection users. Anti-HCV was also significantly higher among persons exposed to reused syringes relative to those with no history of injection use, while no difference was found between non-users and those using new disposable syringes.

Overall HBeAg positivity in the HBsAg-positive cohort was $14.5 \%$. When HBeAg positivity in the study population was disaggregated by province, Khyber Pakhtunkhwa had a lower HBeAg prevalence (8.5\%); however,

\begin{tabular}{|c|c|c|c|c|c|c|}
\hline \multirow[t]{2}{*}{ Variable } & \multicolumn{2}{|c|}{ Males } & \multicolumn{2}{|c|}{ Females } & \multicolumn{2}{|c|}{ Total } \\
\hline & No. (\%) & OR $(95 \% \mathrm{Cl})$ & No. (\%) & OR $(95 \% \mathrm{Cl})$ & No. (\%) & OR $(95 \% \mathrm{Cl})$ \\
\hline \multicolumn{7}{|l|}{ Age (years) } \\
\hline$<5$ & $35(1.7)$ & 1 & $44(2.1) 1$ & 1 & $79(1.6)$ & 1 \\
\hline $5-19$ & $192(2.0)$ & $1.21(0.83-1.77)$ & $187(2.1)$ & $1.00(0.71-1.42)$ & $379(2.1)$ & 1.09 (0.85-1.41) \\
\hline $20-29$ & $170(3.9)$ & $2.43(1.66-3.57)$ & $205(4.8)$ & $2.33(1.66-3.29)$ & $375(4.4)$ & $2.38(1.85-3.06)$ \\
\hline $30-39$ & $204(7.2)$ & $4.62(3.17-6.75)$ & $247(8.4)$ & $4.23(3.02-5.94)$ & $451(7.8)$ & $4.41(3.44-5.66)$ \\
\hline $40-49$ & $261(11.3)$ & 7.56 (5.22-11.0) & $182(8.5)$ & $4.29(3.03-6.08)$ & $443(9.9)$ & $5.75(4.48-7.39)$ \\
\hline $50-59$ & $162(10.9)$ & $7.29(4.96-10.77)$ & $128(9.7)$ & $4.96(3.45-7.15)$ & $290(10.4$ & $6.01(4.63-7.81)$ \\
\hline$\geq 60$ & 180 (10.9) & 7.31 (4.99-10.76) & $97(8.6)$ & $4.32(2.96-6.32)$ & $277(10.0)$ & $5.76(4.43-7.50)$ \\
\hline Total & $1204(4.9)$ & & $1090(4.8)$ & & $2294(4.9)$ & \\
\hline \multicolumn{7}{|l|}{$\begin{array}{l}\text { Marital status (20-49 } \\
\text { years) }\end{array}$} \\
\hline Never married & 139 (3.9) & 1 & $80(3.7)$ & 1 & $219(3.8)$ & 1 \\
\hline Married & $403(6.9)$ & $1.86(1.52-2.28)$ & $532(7.7)$ & $2.17(1.70-2.78)$ & $935(7.3)$ & $2.01(1.72-2.34)$ \\
\hline $\begin{array}{l}\text { Divorced/separated/ } \\
\text { widowed }\end{array}$ & $5(3.6)$ & $0.93(0.33-2.40)$ & $20(9.8)$ & $2.82(1.63-4.83)$ & $25(7.2)$ & $1.99(1.26-3.11)$ \\
\hline Total & $547(5.7)$ & & $632(6.7)$ & & $1179(6.2)$ & \\
\hline \multicolumn{7}{|l|}{$\begin{array}{l}\text { No. of intramuscular } \\
\text { injections }\end{array}$} \\
\hline None & $227(3.8)$ & 1 & $175(3.5)$ & 1 & $402(3.7)$ & 1 \\
\hline$<5$ & $550(4.7)$ & $1.25(1.07-1.47)$ & $457(4.2)$ & $1.20(1.0-1.44)$ & 1007 (4.5) & 1.23 (1.09-1.38) \\
\hline $5-10$ & $312(5.9)$ & $1.58(1.33-1.89)$ & $329(6.4)$ & $1.87(1.54-2.26)$ & $641(6.1)$ & $1.71(1.50-1.95)$ \\
\hline$>10$ & $115(8.1)$ & $2.25(1.77-2.86)$ & $129(8.4)$ & $2.54(1.99-3.23)$ & $244(8.3)$ & $2.38(2.01-2.82)$ \\
\hline Total & $1204(4.9)$ & & $1090(4.8)$ & & 2294 (4.9) & \\
\hline \multicolumn{7}{|l|}{ Types of syringes } \\
\hline None & 227 (3.8) & 1 & 175 (3.5) & 1 & $402(3.7)$ & 1 \\
\hline New disposable & $300(3.7)$ & $0.99(0.83-1.18)$ & $252(3.3)$ & $0.95(0.78-1.16)$ & $552(3.5)$ & $0.97(0.85-1.11)$ \\
\hline Re-used syringe & $615(6.8)$ & $1.87(1.59-2.19)$ & $583(6.7)$ & $1.98(1.66-2.36)$ & $1198(6.8)$ & $1.91(1.70-2.15)$ \\
\hline Don't know & $62(4.3)$ & $1.15(0.85-1.55)$ & $80(5.9)$ & $1.71(1.29-2.27)$ & $142(5.1)$ & 1.41(1.15-1.72) \\
\hline Total & $1204(4.9)$ & & $1090(4.8)$ & & 2305 (4.9) & \\
\hline
\end{tabular}

$C I=$ confidence interval; $O R=$ odds ratio. 


\begin{tabular}{|c|c|c|c|c|}
\hline \multirow[t]{2}{*}{ Variable } & \multicolumn{2}{|c|}{ HBsAg positive } & \multicolumn{2}{|c|}{ Anti-HCV positive } \\
\hline & No. (\%) & OR $(95 \% \mathrm{Cl})$ & No. (\%) & OR $(95 \% \mathrm{Cl})$ \\
\hline \multicolumn{5}{|l|}{ Housing } \\
\hline Kacha home & $696(2.2)$ & 1 & $1726(5.4)$ & 1 \\
\hline Pacca home & $460(3.1)$ & $1.42(1.25-1.60)$ & $568(3.8)$ & $0.69(0.62-0.76)$ \\
\hline \multicolumn{5}{|l|}{ Drinking water } \\
\hline Piped water at home & $604(2.4)$ & 1 & $1425(5.7)$ & 1 \\
\hline $\begin{array}{l}\text { Fetched water from } \\
\text { outside }\end{array}$ & $552(2.4)$ & $0.98(0.87-1.10)$ & 869 (3.7) & $0.64(0.58-0.70)$ \\
\hline \multicolumn{5}{|l|}{ Sanitation } \\
\hline Flush toilet available & $555(2.1)$ & 1 & $1318(5.1)$ & 1 \\
\hline $\begin{array}{l}\text { Pit latrine at home or } \\
\text { going to field }\end{array}$ & $601(2.8)$ & $1.33(1.18-1.50)$ & $976(4.6)$ & $0.90(0.83-0.98)$ \\
\hline \multicolumn{5}{|l|}{ Education } \\
\hline Primary and above & $411(2.3)$ & 1 & $729(4.0)$ & 1 \\
\hline Below primary & $745(2.6)$ & $1.15(1.01-1.30)$ & $1565(5.4)$ & $1.38(1.26-1.51)$ \\
\hline \multicolumn{5}{|l|}{ Employment } \\
\hline $\begin{array}{l}\text { Self-employed working } \\
\text { from home }\end{array}$ & $418(2.1)$ & 1 & $970(5.0)$ & 1 \\
\hline $\begin{array}{l}\text { Working in government } \\
\text { private sector }\end{array}$ & $230(3.0)$ & $1.43(1.21-1.69)$ & $485(6.4)$ & $1.31(1.17-1.46)$ \\
\hline Casual worker & $51(3.1)$ & 1.47 (1.08-1.99) & $99(6.1)$ & $1.23(0.99-1.53)$ \\
\hline
\end{tabular}

the detected interprovincial differences were not significant.

Table 4 illustrates prevalence of HBsAg and anti-HCV in the study population by housing structure, drinking water, sanitation, level of education and employment status. HBsAg was significantly higher among pacca dwellers, and those using pit latrines or the open field, as well as in those with education less than the primary level, relative to those living in kacha houses, or using flush toilets or having higher education than the primary level respectively. HBsAg was also significantly higher among persons working in the government/ private sector and among daily wageearners, relative to those working from home. Contrary results were found for anti-HCV with regard to housing and sanitary facilities with a higher prevalence among those with relatively better facilities, while having a lower education level and working in the public/pri-

$C I=$ confidence interval; $O R=$ odds ratio.

Table 5 Prevalence of hepatitis B surface antigen (HBsAg) and antibody to the hepatitis C virus (anti-HCV) by culture-related risk factors

\begin{tabular}{|c|c|c|c|c|c|}
\hline \multirow[t]{2}{*}{ Risk factor } & \multirow{2}{*}{$\begin{array}{l}\text { No. of } \\
\text { subjects }\end{array}$} & \multicolumn{2}{|c|}{ HBsAg positive } & \multicolumn{2}{|c|}{ Anti-HCV positive } \\
\hline & & No. (\%) & OR $(95 \% \mathrm{CI})$ & No. (\%) & OR $(95 \% \mathrm{CI})$ \\
\hline \multicolumn{6}{|c|}{ Shaving (male $\geq 20$ years) } \\
\hline None & 5288 & $180(3.4)$ & 1 & $295(5.6)$ & 1 \\
\hline Home & 1983 & $73(3.7)$ & $1.1(0.8-1.4)$ & $149(7.5)$ & $1.4(1.1-1.7)$ \\
\hline \begin{tabular}{l}
\multicolumn{1}{c}{ Barber } \\
Sharing too \\
years)
\end{tabular} & 5419 & $244(4.1)$ & $1.5(1.2-1.9)$ & $532(9.8)$ & $1.8(1.5-2.1)$ \\
\hline No & 2364 & $1083(2.6)$ & 1 & $2173(5.1)$ & 1 \\
\hline Yes & 476 & $20(4.2)$ & $1.6(1.0-2.7)$ & $41(8.4)$ & $1.6(1.2-2.4)$ \\
\hline \multicolumn{6}{|c|}{$\begin{array}{l}\text { Sharing cigarettes/hookah/bidi } \\
\text { (adults } \geq 20 \text { years) }\end{array}$} \\
\hline No & 23027 & $698(3.0)$ & 1 & $1676(7.3)$ & 1 \\
\hline Yes & 1373 & $75(5.5)$ & $1.8(1.4-2.4)$ & 158 (11.5) & $1.7(1.4-2.0)$ \\
\hline \multicolumn{6}{|c|}{ Tattooing/acupuncture ( $\geq 5$ years) } \\
\hline No & 42606 & $1095(2.6)$ & 1 & $2195(5.2)$ & 1 \\
\hline Yes & 229 & $8(3.5)$ & $1.4(0.6-2.8)$ & $19(8.3)$ & $1.6(1.0-2.7)$ \\
\hline \multicolumn{6}{|c|}{ Ear/nose piercing (female $\geq 5$ years) } \\
\hline No & 5257 & $76(1.5)$ & 1 & $161(3.1)$ & 1 \\
\hline Yes & 15141 & $351(2.3)$ & $1.6(1.2-2.1)$ & $886(5.8)$ & $2.0(1.7-2.4)$ \\
\hline \multicolumn{6}{|c|}{ History of surgery } \\
\hline No & 44697 & $1083(2.4)$ & 1 & $2058(4.6)$ & 1 \\
\hline Yes & 2346 & $73(3.1)$ & $1.3(1.0-1.2)$ & $236(10.1)$ & $2.3(2.0-2.7)$ \\
\hline
\end{tabular}

$C I=$ confidence interval; $O R=$ odds ratio . 
vate sector was associated with a higher exposure to HCV infection.

Table 5 illustrates prevalence of $\mathrm{HB}$ sAg and anti-HCV by exposure to several risk factors. In males aged 20 years and over, HBsAg prevalence was significantly higher among those who were shaved at a barber shop, relative to those who shaved at home or who did not shave at all, while no difference was found between those who shaved at home, relative to those who did not shave at all. AntiHCV prevalence was significantly higher among those shaving either at barber

shops or at home compared with those who did not shave at all. Both HBsAg and HCV were more prevalent among those who shared tooth brush/miswak or cigarettes/hookah and bidi, or had pierced ears or nose, or had a history of surgery. Anti-HCV was also significantly more prevalent among those with a history of tattooing and acupuncture, relative to those who did not.

Figure 1 illustrates the differences in prevalence among the provinces and districts. While overall prevalence of $\mathrm{HCV}$ was $4.8 \%$, the Punjab province had significantly higher prevalence (6.7\%) relative to Sindh (5.0\%), which in turn had significantly higher antiHCV prevalence when compared to Balochistan (1.5\%) or Khyber Pakhtunkhwa (1.1\%).

Overall prevalence of HBsAg was $2.5 \%$, and Balochistan had the highest prevalence $(4.3 \%)$ relative to Sindh (2.5\%) and Punjab (2.4\%), which in turn had significantly higher prevalence in comparison with Khyber Pakhtunkhwa $(1.3 \%)$.

\section{Discussion}
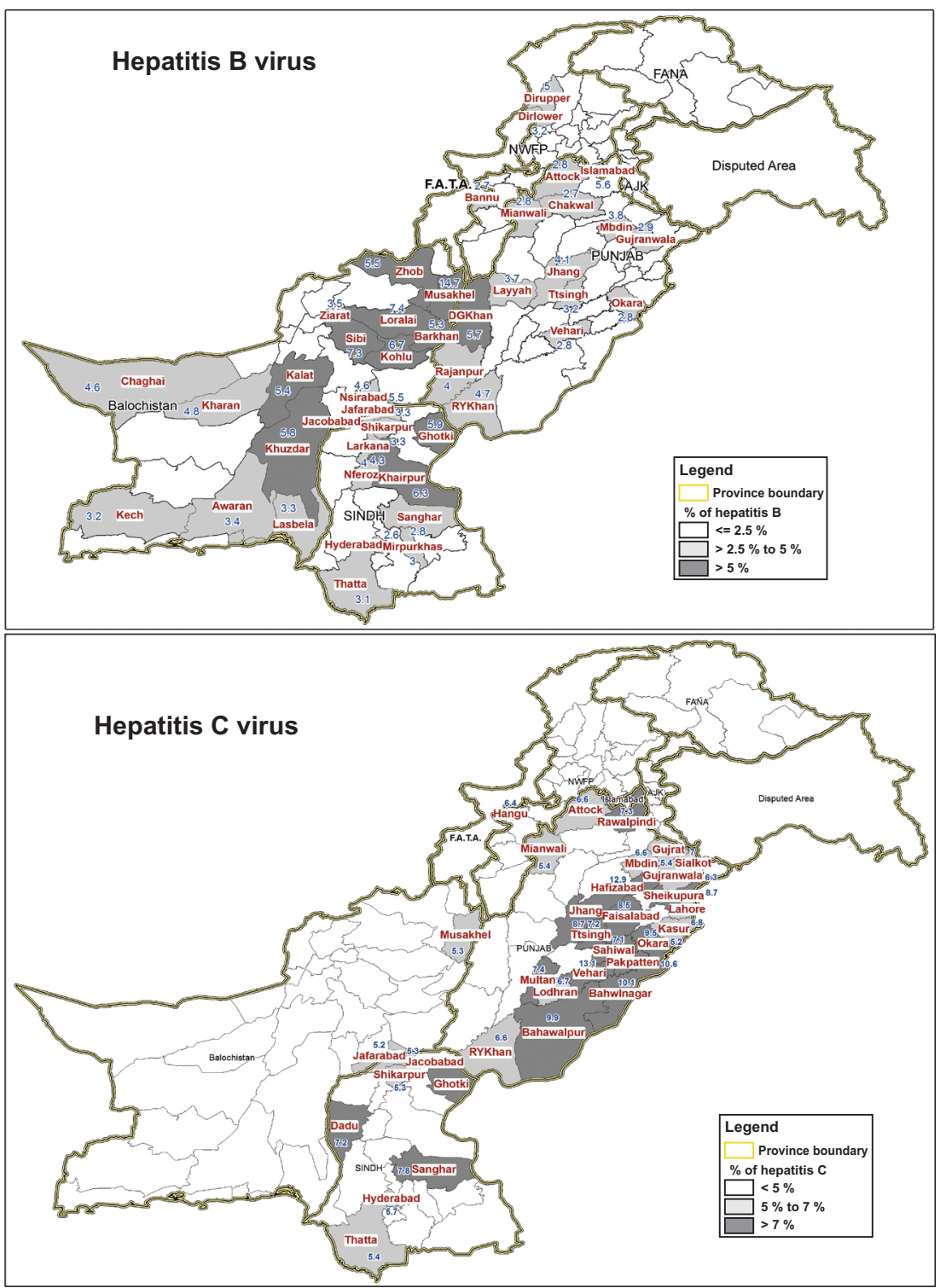

Figure 1 Maps illustrating the geographical burden of hepatitis $B$ and $C$ viral infections in Pakistan. FANA = Federal Administered Northern Areas; FATA = Federally Administered Tribal Areas; NWFP = North West Frontier Area
The HBV and HCV epidemiological studies carried out in Pakistan during past decades had limited geographical scope, different time frames, applied diverse methodologies, and predominantly focused on hospital and highrisk population groups $[4-7,11]$. Despite these considerable diversities and limitations, the studies supported the presence of high HBV and HCV endemicity in Pakistan, promulgating the high burden these viral infections pose to populations' health. These studies determined $\mathrm{HBs} \mathrm{Ag}$ prevalence to range from $2.6 \%$ to $3.5 \%$, while anti-HCV prevalence ranged from $3.3 \%$ to $5.3 \%$, although lower HBV prevalence was reported from blood donors [12-14]. Among CLD patients, 10\%-46\% had HBV infections and 40\%-86\% had anti-HCV [15-18].

The current study has corroborated the above reported high endemicity of $\mathrm{HBV}$ and HCV infections in the country, where the overall HBsAg and anti-HCV cumulative prevalence was $7.6 \%$, reflecting a population pool of about 13 million being $\mathrm{HBV}$ and HCV chronic carriers. These findings are consistent with a current or imminent high burden of liver disease where $25 \%$ of the HBsAg and $80 \%-85 \%$ of the anti-HCV positive individuals may later progress to CLD $[1,8]$.

The association of $\mathrm{HBV}$ infection with increased age, marital status and 
exposure to a series of risk factors including lesser education, outdoor employment, poor sanitation, shaving at the barber, ear/nose piercing and history of surgery corroborates the diverse complementary sources of infection and the need for universal hepatitis $B$ vaccination of all newborn infants and high-risk groups and other hepatitis control preventive interventions. However, the lower level of HBV infection in teenage groups in both sexes may reflect a lesser exposure at that age.

In 2000, Pakistan introduced the monovalent hepatitis $B$ vaccine in the national EPI and replaced it in 2008 with the pentavalent vaccine where hepatitis $B$ vaccine is jointly administered with diphtheria, tetanus, pertussis and Haemophilus influenzae $\mathrm{B}$ vaccines, reducing the number of child vaccination contacts to improve vaccine acceptability and wastage control. Unfortunately, the current performance of the EPI shows that a large number of newborns miss the opportunity of accessing these regularly procured vaccines, reflecting the unnecessary avoidable harm to which many children are exposed.

However, the study could not exclude the importance of vertical transmission, a matter requiring a focused study to evaluate the need for corresponding preventive interventions. The higher prevalence of HBV among married individuals may reflect the potential of sexual transmission, this being an epidemiologically recognized mode of infection, mandating public education about this risk of infection transition [19].

The higher association of HBV infection with lower socioeconomic conditions and exposure to related risk factors categorizes hepatitis $B$ as a disease of poverty, where the aforementioned lower immunization coverage in children residing in underprivileged areas raises concerns of inequity. Moreover, these finding give directions for ensuring the vaccination of high-risk groups, especially the health workforce, and promotion of infection-control safety measures when undertaking traditional practices entailing the use of invasive devices.

The incremental age-related prevalence ofHCVinfection reflectsincreased exposure to high-risk practices such as the widespread reuse of syringes and a range of high risky traditional practices. These behaviours need to be controlled, both among health providers and in the community at large, as out of $95 \%$ of the globally used injections administered for therapeutic purposes, $50 \%$ were unsafe while $80 \%$ were unnecessary $[20,21]$. This observation is strongly substantiated by the evident correlation between anti-HCV prevalence and the reuse of syringes and frequency of injection use. High community exposure to unsafe injections may also account for the observed lack of gender variation in $\mathrm{HCV}$ prevalence. These findings call for the promotion of a nationwide injection safety programme in all health facilities where related guidelines become an integral part of a patient safety intervention with adherence to the fundamentals of quality of care. The common use of multidose vials also needs to be discouraged and practice by quacks prevented through the promotion of public awareness against these risky though traditional practices.

The corroborated greater HBV and HCV risk of infection associated with the history of surgery substantiates the need for improving the safety of surgical care. While transmission of HBV can be tangibly controlled in a few decades through an effective universal vaccination of the identified target population groups coupled with public education and behaviour change communication, for $\mathrm{HCV}$, where vaccination is not an option, public education and advocacy control interventions must be supplemented by the universal use of auto-disable syringes that should replace reusable disposable syringes in the country. Health authorities may also expedite the introduction of injection and patient safety measures in all health facilities and the setting of strategic policies that curtail the use of multidose vials, including those obtained from veterinary sources and misused by quacks.

Moreover, the currently pursued nationwide free treatment for underprivileged CLD patients needs to be sustained, as this constitutes a health intervention mitigating poverty, generating public support for the programme and impacting on the quality of life of these patients.

\section{References}

1. Lavanchy D. The global burden of hepatitis C. Liver International, 2009, 29(s1):74-81.

2. Shepard CW, Finelli L, Alter MJ. Global epidemiology of hepatitis C virus infection. Lancet, 2005, 5:558-567.

3. Rantala M, Van de Laar MJW. Surveillance and epidemiology of hepatitis B and C in Europe - a review. Eurosurveillance, 2008, 13(4-6):1-8

4. Ali SA et al. Hepatitis B and hepatitis C in Pakistan: prevalence and risk factors. International Journal of Infectious Diseases, 2009, 13:9-19.
5. Khan TS, Rizvi F. Hepatitis B seropositivity among chronic liver disease patients in Hazara division Pakistan. Journal of Ayub Medical College Abottabad, 2003, 15(3):54-55.

6. Raja NS, Janjua KA. Epidemiology of hepatitis $\mathrm{C}$ virus infection in Pakistan. Journal of Microbiology, Immunology and Infection, 2008, 41:4-8.

7. Khan ZA, Aslam MI, Ali S. The frequency of hepatitis B and $\mathrm{C}$ among volunteer blood donors in Balochistan. Hepatitis Monthly, 2007, 7(2):73-76. 
8. Van Damme $P$, Kane $M$, Andre M. Integration of hepatitis B vaccination into national immunization programmes. British Medical Journal, 1997, 314(7086):1033.

9. Global progress towards universal childhood hepatitis B vaccination. Weekly Epidemiological Record, 2003, 78(42):366-370.

10. Hepatitis C. Weekly Epidemiological Record, 1997, 72(10):6569.

11. Farooqi JI, Farooqi RJ. Relative frequency of hepatitis "B" virus and hepatitis " $\mathrm{C}$ " virus infections in patients of cirrhosis in NWFP. Journal of the College of Physicians and Surgeons-Pakistan, 2000, 10(6):217-219.

12. Khokhar N, Gill ML, Malik G J. General seroprevalence of hepatitis $\mathrm{C}$ and hepatitis $\mathrm{B}$ virus infections in population. Journal of the College of Physicians and Surgeons-Pakistan, 2004, 14(9):534-536.

13. Ali $\mathrm{N}$ et al. Prevalence of hepatitis B surface antigen and hepatitis $\mathrm{C}$ antibodies in young healthy adults. Pakistan Journal of Pathology, 2002, 13(2):3-6.

14. Kakepoto GN et al. Epidemiology of blood borne viruses: a study of healthy blood donors in Southern Pakistan. Southeast Asian Journal of Tropical Medicine and Public Health, 1996, 27(4):703-706.
15. Masud I, Khan H, Khatak AM. Relative frequency of hepatitis B and $C$ viruses in patients with hepatic cirrhosis at DHQ teaching hospital D. I. Khan. Journal of Ayub Medical College Abottabad, 2004, 16(1):32-34

16. Khokhar N. Spectrum of chronic liver disease in a tertiary care hospital. Journal of Pakistan Medical Association, 2002, 52(2):56-58.

17. Khan AA et al. Seromarkers of hepatitis B and C in patients with cirrhosis. Journal of the College of Physicians and SurgeonsPakistan, 2002, 12(2):105-107.

18. Khan TS, Rizvi F, Rashid A. Hepatitis C seropositivity among chronic liver disease patients in Hazara, Pakistan. Journal of Ayub Medical College Abottabad, 2003, 15(2): 53-55.

19. Bile K et al. Late seroconversion to hepatitis B in a Somali village indicates the important role of venereal transmission. Journal of Tropical Medicine and Hygiene, 1991, 94:367-373.

20. Simonsen $L$ et al. Unsafe injections in the developing world and transmission of bloodborne pathogens: A review. Bulletin of the World Health Organization, 1999, 77(10):789-800.

21. Kermode M. Unsafe injections in low-income country health settings: need for injection safety promotion to prevent the spread of blood-borne viruses. Health Promotion International, 2004, 19(1):95-103. 